\title{
Quantification of Hepatitis B Virus Covalently Closed Circular DNA in Infected Cell Culture Models by Quantitative PCR
}

Bingqian $\mathrm{Qu}^{1}$ and Stephan Urban ${ }^{1,2, *}$

\begin{abstract}
1Department of Infectious Diseases, Molecular Virology, Centre for Integrative Infectious Disease Research (CIID), University Hospital Heidelberg, Heidelberg, Germany; ${ }^{2}$ German Centre for Infection Research (DZIF), Partner Site Heidelberg, Heidelberg, Germany

*For correspondence: Stephan.Urban@med.uni-heidelberg.de
\end{abstract}

[Abstract] Persistence of the human hepatitis B virus (HBV) requires the maintenance of covalently closed circular (ccc)DNA, the episomal genome reservoir in nuclei of infected hepatocytes. cccDNA elimination is a major aim in future curative therapies currently under development. In cell culture based in vitro studies, both hybridization- and amplification-based assays are currently used for cccDNA quantification. Southern blot, the current gold standard, is time-consuming and not practical for a large number of samples. PCR-based methods show limited specificity when excessive HBV replicative intermediates are present. We have recently developed a real-time quantitative PCR protocol, in which total cellular DNA plus all forms of viral DNA are extracted by silica column. Subsequent incubation with T5 exonuclease efficiently removes cellular DNA and all non-cccDNA forms of viral DNA while cccDNA remains intact and can reliably be quantified by PCR. This method has been used for measuring kinetics of cccDNA accumulation in several in vitro infection models and the effect of antivirals on cccDNA. It allowed detection of cccDNA in non-human cells (primary macaque and swine hepatocytes, etc.) reconstituted with the HBV receptor, human sodium taurocholate cotransporting polypeptide (NTCP). Here we present a detailed protocol of this method, including a work flowchart, schematic diagram and illustrations on how to calculate "cccDNA copies per (infected) cell".

Keywords: Hepatitis B Virus, Covalently closed circular DNA, cccDNA, T5 exonuclease, Quantitative PCR, Copy number per cell

[Background] The Hepatitis B virus (HBV), a DNA virus belonging to the family Hepadnaviridae, is a human pathogen persisting in approximately 240 million people globally. HBV infection leads to higher risks of liver cirrhosis and hepatocellular carcinoma (Liang et al., 2015). At present, chronic HBV infection is not curable as current treatments do not eradicate the replicative reservoir, covalently closed circular (ccc)DNA (Levrero et al., 2016). In in vitro infected hepatocytes, cccDNA is formed by cellular repair of relaxed circular duplex (rc)DNA, the genomic form in virions (Guo et al., 2007; Long et al., 2017; Schreiner and Nassal, 2017). cccDNA serves as the viral template for pregenomic RNA which becomes encapsidated into nucleocapsids and is reverse transcribed to generate rcDNA and double-stranded linear (dsl)DNA by the viral polymerase (Bartenschlager and Schaller, 1992; Tu et al., 2017). Of note, albeit the reconstitution of hepatoma cells with the receptor human sodium taurocholate cotransporting polypeptide (NTCP), high excess of inoculated virions with high multiple genome equivalents (mges) 
(mges $>100$ ) is required to achieve moderate infection rates (e.g., > 20\% in HepG2 ${ }^{\mathrm{NTCP}}$ cells) (Qu et al., 2018). This raises the problem that cccDNA-containing samples taken early after inoculation with HBV contain large amounts of rcDNA from input virions.

Therefore, adequate methodologies for absolute or relative quantification of cccDNA are required. They are divided into two categories: (I) hybridization after separation by gel electrophoresis (Southern blot) and (II) PCR amplification (Li et al., 2017). Southern blot is still a gold standard but not very sensitive, and demands multiple experimental processes and a high-copy load of cccDNA ( $>2 \times 10^{6}$ copies using ${ }^{32} \mathrm{P}$-radioactive isotope/digoxigenin/biotin probe; $>1 \times 10^{4}$ copies using branched DNA technique) (Yu et al., 2015). Therefore, hybridization-based methods are complicated, time-consuming and not practical for a large number of samples (e.g., > 20) to be analyzed in parallel. PCR methods include real-time quantitative (q)PCR, nested qPCR (Xu et al., 2011), digital-droplet PCR (Mu et al., 2015), and rolling circle amplification (Margeridon et al., 2008). Real-time qPCR is the fastest and the most robust method for almost all laboratories. However, unlike Southern blot which gel electrophoretically separates cccDNA, PCR methods are not strictly specific, especially when rcDNA and other HBV replicative intermediates are present in excess, such as in in vitro infection (e.g., MGE > 300), even when cccDNAspecific primer pairs are used (Nassal, 2015; Qu et al., 2018).

To solve this problem, we have developed a qPCR assay using validated cccDNA selective primer pairs and a digestion step by T5 exonuclease, which removes cellular DNA and all HBV intermediates via its exonuclease activity targeting free ends of rcDNA and dsIDNA but leaves cccDNA intact (Qu et al., 2018). This assay allowed fast and specific quantification of cccDNA within one working day as shown in Figure 1 ( $2 \mathrm{~h}$ of total DNA extraction; $1.5 \mathrm{~h}$ of T5 exonuclease reaction and $2 \mathrm{~h}$ of $\mathrm{qPCR}$ ), accurate calculation of "cccDNA copies/(infected) cell" (Figure 2) and drug efficacy testing on cccDNA levels (Figure 3). The method also provided quantitative judgment on whether cccDNA is formed in new cell models and identified low amount of cccDNA in in vitro infection of non-primate hepatocytes (Lempp et al., 2016 and 2017). This protocol is adapted from Qu et al. (2018) and herein more detailed information on this qPCR quantification after T5 exonuclease digestion is included, and different primer pairs are compared to address the applicability of HBV genotypes. Taken together, this protocol will facilitate studies on cccDNA and help clinicians, technicians and graduate students to analyze cccDNA in samples derived from in vitro infection.

\section{Materials and Reagents}

1. Pipette tips (Neptune, $1,000 \mu \mathrm{l}, 200 \mu \mathrm{l}, 20 \mu \mathrm{l}, 10 \mu \mathrm{l}$, DNase-/RNase-free \& Biozym, premium tips $1000 \mu \mathrm{l}, 200 \mu \mathrm{l}, 10 \mu \mathrm{l})$

2. $1.5 \mathrm{ml}$ microcentrifuge tube (Sarstedt AG \& Co.KG, SafeSeal tube, catalog number: 72.706 )

3. $0.2 \mathrm{ml}$ microcentrifuge tube (Greiner Bio-one, Sapphire PCR tube, catalog number: 683271)

4. Hard-Shell PCR plates 96-well, thin-wall (Bio-rad, catalog number: HSP9601)

5. Primary human hepatocytes $(\mathrm{PHH})$ (obtained from Hannover medical school or prepared in University Hospital Heidelberg) (Possible commercial vendors of PHH are Lonza, Biopredic, 
BiolVT, ThermoFisher, however susceptibility to HBV may vary), HepaRGNTCP and HepG2 ${ }^{\text {NTCP }}$ cell lines (Qu et al., 2018)

6. Plasmid pSHH2.1 (Cattaneo et al., 1983), available upon request from the corresponding author

7. Primers:

Primer p1040: 5'-GTGGTTATCCTGCGTTGAT-3'

Primer p1996: 5'-GAGCTGAGGCGGTATCT-3'

p1578: 5'-CCGTGTGCACTTCGCTTCA-3'

p1867: 5'-GCACAGCTTGGAGGCTTGA-3'

p1583: 5'-TGCACTTCGCTTCACCT-3'

p2301: 5'-AGGGGCATTTGGTGGTC-3'

8. Probe

Probe p1085: 5'-FAM-AGTTGGCGAGAAAGTGAAAGCCTGC-TAMRA-3'

9. Trypsin [0.25\% Trypsin-EDTA (1x)] (Invitrogen, Gibco, catalog number: 25200-056), $4{ }^{\circ} \mathrm{C}$

10. NucleoSpin Tissue kit (Macherey-Nagel, catalog number: 740952.250)

11. Buffer T1 (Macherey-Nagel, catalog number: 740940.25)

12. Proteinase $\mathrm{K}$ (Macherey-Nagel, catalog number: 740506 ), $-20^{\circ} \mathrm{C}$

13. Buffer B3 (Macherey-Nagel, catalog number: 740920)

14. Ethanol absolute (VWR chemicals, catalog number: 20821.330)

15. Buffer BW (Macherey-Nagel, catalog number: 740922)

16. Buffer B5 Concentrate (Macherey-Nagel, catalog number: 740921)

17. T5 exonuclease (New England Biolabs, catalog number: M0363), $-20^{\circ} \mathrm{C}$

18. NEBuffer 4 (New England Biolabs, catalog number: B7004), $-20^{\circ} \mathrm{C}$ in aliquots

19. PerfeCTa qPCR Toughmix (Quanta Biosciences, catalog number: $95112-012$ ), $-20^{\circ} \mathrm{C}$ in aliquots

20. SYBR Green Supermix (Bio-Rad, catalog number: $172-5121$ ), $-20^{\circ} \mathrm{C}$ in aliquots

21. Myrcludex $B$ (Bachem), available upon request from the corresponding author, $-80^{\circ} \mathrm{C}$ in aliquots

22. Recombinant human Interferon- $\alpha-2 a$ (PeproTech, catalog number: $300-02 \mathrm{AA}),-80{ }^{\circ} \mathrm{C}$ in aliquots

23. Human Interferon- $\alpha-2 a$ (PBL Assay Science, catalog number: $11100-1),-80{ }^{\circ} \mathrm{C}$ in aliquots

24. Nuclease-free water (B. Braun Melsungen, Aqua ad iniectabilia Braun)

25. $\mathrm{NaCl}$ (Carl Roth $\mathrm{GmbH}$, catalog number: 9265.2)

26. $\mathrm{KCl}$ (Sigma-Aldrich, catalog number: 31248)

27. $\mathrm{Na}_{2} \mathrm{HPO}_{4} \cdot 2 \mathrm{H}_{2} \mathrm{O}$ (Sigma-Aldrich, catalog number: 04272)

28. $\mathrm{KH}_{2} \mathrm{PO}_{4}$ (Sigma-Aldrich, catalog number: P9791)

29. Tris-base (Carl Roth $\mathrm{GmbH}$, catalog number: 4855.2)

30. Dimethyl sulfoxide (Sigma-Aldrich, catalog number: 1.02950)

31. Fetal bovine serum gold (PAA Laboratories $\mathrm{GmbH}$, catalog number: $\mathrm{A} 15-151$ ), $-20^{\circ} \mathrm{C}$

32. Penicillin/Streptomycin (Thermo Fisher Scientific, catalog number: $15140-122$ ), $4{ }^{\circ} \mathrm{C}$

33. L-glutamine (Thermo Fisher Scientific, catalog number: $25030-024), 4{ }^{\circ} \mathrm{C}$

34. MEM non-essential amino acids (Thermo Fisher Scientific, catalog number: $11140-035$ ), $4{ }^{\circ} \mathrm{C}$ 
35. Recombinant insulin (Sigma-Aldrich, catalog number: $91077 \mathrm{C}-1 \mathrm{G}$ ), $-20^{\circ} \mathrm{C}$ in aliquots

36. Hydrocortisone 21-hemisuccinate sodium salt (Sigma-Aldrich, catalog number: $\mathrm{H} 4881$ ), $-20^{\circ} \mathrm{C}$ in aliquots

37. Culture medium (see Recipes)

38. 10x PBS buffer (see Recipes)

39. $5 \mathrm{mM}$ Tris- $\mathrm{HCl}$ (see Recipes)

\section{Equipment}

1. Pipettes (Gilson P1000, P200, P20; Eppendorf P2.5)

2. Cell counter (Bio-Rad, TC20 ${ }^{\mathrm{TM}}$ Automated Cell Counter, catalog number: 1450102)

3. Thermomixer (Eppendorf, ThermoMixer C, catalog number: 5382000015)

4. Microcentrifuge (Thermo Fisher Scientific, Heraeus ${ }^{\mathrm{TM}}$ Pico $^{\mathrm{TM}} 21$ Centrifuge, catalog number: 75002553)

5. Thermocycler (Labrepco, Biometra T3000 Thermocycler 48, catalog number: 050-723)

6. qPCR thermocycler (Bio-Rad, C1000 Touch ${ }^{\mathrm{TM}}$ Thermal cycler with 96-well Fast Reaction Module, catalog number: 1851196)

\section{Software}

1. CFX96 Real-time System

(Bio-Rad, http://www.bio-rad.com/en-us/product/cfx96-touch-real-time-pcr-detection-system)

2. CFX Manager ${ }^{\mathrm{TM}}$ Software

(Bio-Rad, http://www.bio-rad.com/en-us/sku/1845000-cfx-manager-software?ID=1845000) 


\section{Procedure}

HBV in vitro infection (days - weeks)
(A) DNA extraction $\rightarrow$ $(2-3 h)$
(B) T5 exonuclease reaction $\rightarrow$ $(\sim 2 \mathrm{~h})$
(C) cccDNA quantification

$(2-3 h)$

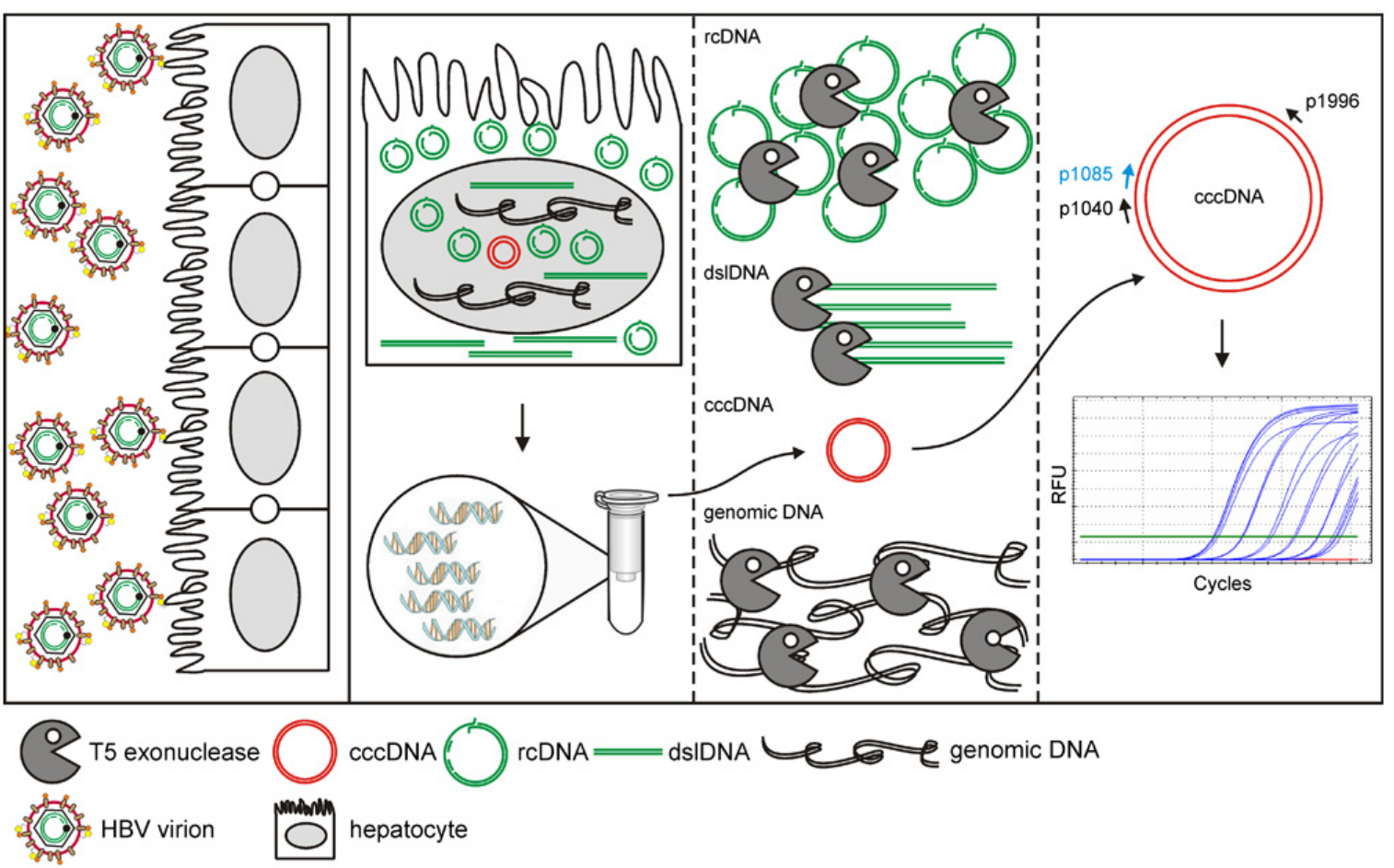

Figure 1. Working flowchart of this protocol. Susceptible cells (PHH, HepaRG ${ }^{N T C P}$, HepG2 ${ }^{\mathrm{NTCP}}$ ) infected with high mges (>300) of HBV are lysed. A. Lysates are incubated at $70{ }^{\circ} \mathrm{C}$ in the presence of proteinase $\mathrm{K}$ and later loaded on silica column and eluted. B. T5 exonuclease ( 5 units $/ 1 \mathrm{~h}$ ) removes host genomic DNA (black) and HBV replicative intermediates (rcDNA, dsIDNA, etc.) (green) and preserves cccDNA (red) intact. C. cccDNA is amplified by p1040/p1996 and detected by probe p1085.

A. HBV DNA extraction from in vitro infected hepatocytes (Figure 1A)

1. For infection performed in a 24-well plate (culture area: $2 \mathrm{~cm}^{2}$ ), trypsinize and resuspend infected PHH, differentiated HepaRG ${ }^{\mathrm{NTCP}}$ or HepG2 ${ }^{\mathrm{NTCP}}$ cells (infection procedure see $\mathrm{Ni}$ and Urban, 2017) in $1 \mathrm{ml}$ of culture medium. Take $10 \mu \mathrm{l}$ of the resuspension for cell count by a cell counter (see Equipment). Calculate total cell numbers.

Notes:

a. At confluency, cells in one well of a 24-well plate approximately correspond to 180,000 $\mathrm{PHH}$, 200,000 HepaRG ${ }^{N T C P}$ and 500,000 HepG2 ${ }^{\text {NTCP }}$ cells.

b. When smaller or larger plates are used, volumes of the respective buffers given in the protocol should be adjusted according to the respective culture area $\left(\mathrm{cm}^{2}\right)$ of a well.

2. Spin down the cells (900 $\times \mathrm{g}, 5 \mathrm{~min}$ ) at room temperature. Wash cells with $1 \mathrm{ml}$ of PBS twice. Spin down the cells and carefully aspirate PBS (Optional: freeze cell pellet at $-20^{\circ} \mathrm{C}$ for longterm storage). For DNA extraction, manufacturer's manual of the NucleoSpin Tissue kit 
(740952.250) is adapted with a minor modification regarding the incubation time in Step A2 (1 $\mathrm{h}$ instead of $10 \sim 15 \mathrm{~min})$ and the elution volume in Step A6 (50 $\mu \mathrm{l}$ instead of $100 \mu \mathrm{l})$. Add $200 \mu \mathrm{l}$ of lysis buffer T1, pipet up and down and incubate at room temperature for $10 \mathrm{~min}$. Add $25 \mu \mathrm{l}$ of proteinase $\mathrm{K}$ and $200 \mu \mathrm{l}$ of lysis buffer $\mathrm{B} 3$, vortex and incubate the lysate at $70{ }^{\circ} \mathrm{C}$ for $1 \mathrm{~h}$ with shaking (500 rpm).

Note: After proteinase $K$ digestion, it is not necessary to re-centrifuge the lysates. Immediately perform the next step.

3. Add $210 \mu \mathrm{l}$ of ethanol $(96 \%-100 \%)$ to the sample and vortex vigorously for a few seconds. Remove buffer from the lid by a short centrifugation and apply the samples to the column. Centrifuge (11,000 $\times \mathrm{g}, 1 \mathrm{~min})$ at room temperature. Discard flow-through.

4. Add $500 \mu \mathrm{l}$ of wash buffer BW. Centrifuge $(11,000 \times \mathrm{g}, 1 \mathrm{~min})$ at room temperature. Discard flowthrough.

5. Add $600 \mu$ l of wash buffer B5 (pre-add indicated volume of ethanol to the Buffer B5 Concentrate) to the column. Centrifuge $(11,000 \times \mathrm{g}, 1 \mathrm{~min})$ at room temperature. Discard flow-through. Repeat this step once.

6. Remove residual ethanol from the column $(13,000 \times \mathrm{g}, 1 \mathrm{~min})$. Place the column into a $1.5 \mathrm{ml}$ microcentrifuge tube. Add $50 \mu \mathrm{l}$ of pre-warmed $\left(70^{\circ} \mathrm{C}\right)$ elution buffer. Incubate at room temperature for $1 \mathrm{~min}$. Centrifuge $(11,000 \times \mathrm{g}, 1 \mathrm{~min})$. Freeze eluted DNA samples at $-20^{\circ} \mathrm{C}$ until use or analyze them immediately.

Notes:

a. Elution buffers are nuclease-free water or $5 \mathrm{mM}$ Tris- $\mathrm{HCl}(\mathrm{pH}=8.0)$. Do not use buffers with EDTA that may inhibit enzymatic activity in the next step.

b. DNA concentration in eluates is $200-1,000 \mathrm{ng} / \mu \mathrm{l}$.

c. Preserve at least $10 \mu \mathrm{l}$ of the sample without T5 exonuclease digestion for quantification of $\beta$-globin (internal standard) for normalization use.

B. T5 exonuclease hydrolysis of total DNA elutes (Figure 1B)

1. Assemble the reaction components in a $0.2 \mathrm{ml}$ microcentrifuge tube following the table as shown:

\begin{tabular}{|l|l|}
\hline Component & Volume \\
\hline 10x NEBuffer 4 & $1 \mu \mathrm{l}$ \\
\hline T5 exonuclease $(10 \mathrm{U} / \mu \mathrm{l})$ & $0.5 \mu \mathrm{l}(5 \mathrm{U})$ \\
\hline Crude DNA eluate $(<5 \mu \mathrm{g})$ & $5 \mu \mathrm{l}$ \\
\hline Nuclease-free water & $3.5 \mu \mathrm{l}$ \\
\hline Total volume & $10 \mu \mathrm{l}$ \\
\hline
\end{tabular}

Note: Do not exceed unit and incubation time of T5 exonuclease since overdigestion leads to partial loss of cccDNA.

2. Incubate the reaction at $37{ }^{\circ} \mathrm{C}$ for $1 \mathrm{~h}$ and inactivate the enzyme at $70{ }^{\circ} \mathrm{C}$ for 20 min in a thermocycler with heat-lid supply. 
3. Proceed quantification by real-time $\mathrm{qPCR}$ or freeze the products at $-20^{\circ} \mathrm{C}$ until use.

C. Quantification of cccDNA relative to human $\beta$-globin (single-copy gene) by real-time qPCR (Figure 1C)

1. Quantification of cccDNA

a. Dilute primers and probe to $10 \mu \mathrm{M}$ :

\begin{tabular}{|l|l|}
\hline Primer/Probe & Sequence \\
\hline Forward primer p1040 & 5'-GTGGTTATCCTGCGTTGAT-3' (see Notes section) \\
\hline Reverse primer p1996 & 5'-GAGCTGAGGCGGTATCT-3' (see Notes section) \\
\hline Probe p1085 & 5'-FAM-AGTTGGCGAGAAAGTGAAAGCCTGC-TAMRA-3' \\
\hline
\end{tabular}

FAM: 6-carboxyfluorescein; TAMRA: 6-carboxytetramethylrhodamine

b. Prepare the following qPCR reactions in a 96-well Hard-Shell PCR plate:

\begin{tabular}{|l|l|}
\hline Component & Volume \\
\hline 2x PerfeCTa qPCR ToughMix & $7.5 \mu \mathrm{l}$ \\
\hline p1040 $(10 \mu \mathrm{M})$ & $0.6 \mu \mathrm{l}$ (final concentration: $400 \mathrm{nM})$ \\
\hline p1996 $(10 \mu \mathrm{M})$ & $0.6 \mu \mathrm{l}$ (final concentration: $400 \mathrm{nM})$ \\
\hline p1085 $(10 \mu \mathrm{M})$ & $0.6 \mu \mathrm{l}$ (final concentration: $400 \mathrm{nM})$ \\
\hline DNA sample after T5 exonuclease treatment & $2 \mu \mathrm{l} \#$ \\
\hline Nuclease-free water & $3.7 \mu \mathrm{l}$ \\
\hline Total volume & $15 \mu \mathrm{l}$ \\
\hline
\end{tabular}

\#for absolute quantification, load $2 \mu \mathrm{l}$ of each 1:10 serial-diluted plasmid $\left(\mathrm{pSHH} 2.1: 10^{9}, 10^{8}\right.$, $10^{7}, 10^{6}, 10^{5}, 10^{4}, 10^{3}, 10^{2}$ copies/ $\mu$ l) as templates on the same plate.

c. Run qPCR program below:

\begin{tabular}{|l|l|l|l|}
\hline Step & Temperature & Time & Signal collection \\
\hline 1 & $95^{\circ} \mathrm{C}$ & $15 \mathrm{~min}$ & Off \\
\hline 2 & $95^{\circ} \mathrm{C}$ & $5 \mathrm{~s}$ & Off \\
\hline 3 & $63^{\circ} \mathrm{C}$ & $70 \mathrm{~s}$ & On \\
\hline \multicolumn{2}{|l}{ Repeat steps 2 and 3 for 50 cycles } \\
\hline
\end{tabular}

d. Read absolute cccDNA copy numbers in the CFX Manager ${ }^{\mathrm{TM}}$ Software. Calculate cccDNA copies per well.

2. Quantification of human $\beta$-globin prior to T5 exonuclease digestion

a. Dilute primers at $10 \mu \mathrm{M}$ : 


\begin{tabular}{|l|l|}
\hline Primer & Sequence \\
\hline Forward primer $\beta$-globin & 5'-CAGGTACGGCTGTCATCACTTAGA-3' \\
\hline Reverse primer $\beta$-globin & 5'-CATGGTGTCTGTTTGAGGTTGCTA-3' \\
\hline
\end{tabular}

b. Prepare qPCR reactions in a 96-well plate:

\begin{tabular}{|l|l|}
\hline Component & Volume \\
\hline 2x SYBR green Supermix & $7.5 \mu \mathrm{l}$ \\
\hline Forward primer $(10 \mu \mathrm{M})$ & $0.6 \mu \mathrm{l}$ (final concentration: $400 \mathrm{nM})$ \\
\hline Reverse primer $(10 \mu \mathrm{M})$ & $0.6 \mu \mathrm{l}$ (final concentration: $400 \mathrm{nM})$ \\
\hline $\begin{array}{l}\text { DNA sample prior to } \\
\text { T5 exonuclease treatment }\end{array}$ & $2 \mu \mathrm{l}$ \\
\hline Nuclease-free water & $4.3 \mu \mathrm{l}$ \\
\hline Total volume & $15 \mu \mathrm{l}$ \\
\hline
\end{tabular}

c. Start qPCR program below:

\begin{tabular}{|l|l|l|l|}
\hline Step & Temperature & Time & Signal collection \\
\hline 1 & $95^{\circ} \mathrm{C}$ & $10 \mathrm{~min}$ & Off \\
\hline 2 & $95^{\circ} \mathrm{C}$ & $5 \mathrm{~s}$ & Off \\
\hline 3 & $60^{\circ} \mathrm{C}$ & $30 \mathrm{~s}$ & On \\
\hline \multicolumn{2}{|l|}{ Repeat steps 2 and 3 for 40 cycles }
\end{tabular}

d. Read levels of human $\beta$-globin. Normalize cccDNA copies per well using values of human $\beta$-globin. Calculate cccDNA copies per cell (copies per well divided by cell numbers per well). For instance, if cell numbers in a well of 24-well plate are $4.2 \times 10^{5}$ (as determined in Procedure A1) and cccDNA copies per well are $8.52 \times 10^{5}$ (as determined in Procedure C), cccDNA copies per cell are 2.03 .

\section{Data analysis}

cccDNA copy number per cell or infected cell is calculated according to Figure 2. The cccDNA level in in vitro infected cells can be determined similarly as two examples shown in Figure 3 and Qu et al., 2018. Note that to discriminate signals from the inoculum, we highly recommend using an entry inhibitor (e.g., Myrcludex B) as a control. Routinely Myrcludex B control gives a value below 0.05 copy per infected cell. 
In vitro HBV infection (MGE/cell=300, etc)

(A) Counting cell numbers prior to DNA extraction

(B) DNA extraction (day 7, etc.) elute DNA in $50 \mu \mathrm{L}$ of $\mathrm{H}_{2} \mathrm{O}$

(C) T5 exonuclease reaction: DNA elute $5 \mu \mathrm{L}$ $\mathrm{H}_{2} \mathrm{O}$ $3.5 \mu \mathrm{L}$ NEBuffer $4 \quad 1 \mu \mathrm{L}$ T5 exonuclease $0.5 \mu \mathrm{L}$ Total $\quad 10 \mu \mathrm{L}$

$37^{\circ} \mathrm{C}$ for 1 hour $70^{\circ} \mathrm{C}$ for 20 minutes

(D) $\underline{\text { ccDNA gPCR }}$

Calculate cccDNA copies/well

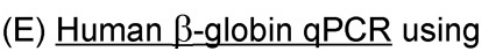
undigested DNA samples
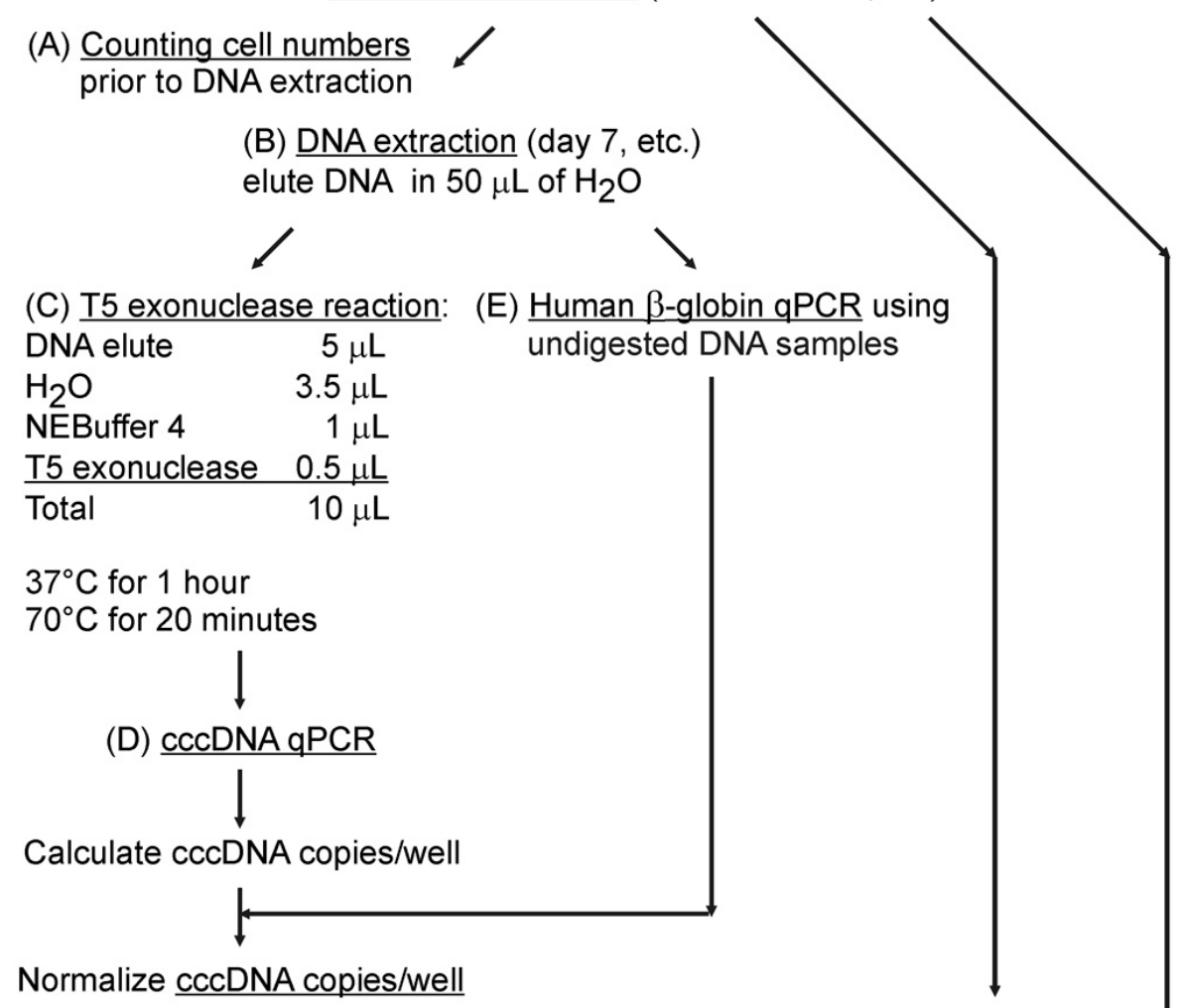

$\longmapsto$ (A)

Calculate cccDNA copies/cell

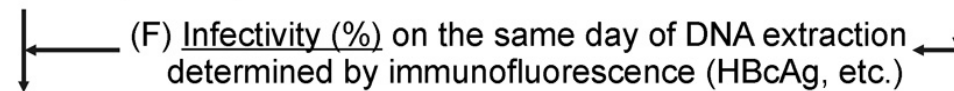

Calculate cccDNA copies/infected cell

Figure 2. Schematic diagram of the calculation of absolute cccDNA copy numbers. A. On the day of experiment, cell number in the well is determined. B. Total DNA samples are extracted as suggested in Procedure. C. Here shows a proper T5 exonuclease digestion as shown in Procedure. D. Absolute cccDNA copies and $E$ level of human $\beta$-globin are quantified, respectively as shown in Procedure. "cccDNA copies/cell" is "cccDNA copies/well" divided by "cell numbers". Optional: F. If calculation of copies per infected cell is required, additional wells have to be arranged in parallel on the same plate during the infection. On the day of DNA extraction, cells in the wells are fixed and subjected to an immunofluorescence assay ( $\mathrm{HBcAg}$ visualization using DAKO B0586 antibody, etc.) to determine infectivity (\%: number of $\mathrm{HBcAg}$ positive cells divided by number of total cells) (Qu et al., 2018). "cccDNA copies/infected cell" is the "cccDNA copies/cell" divided by "infectivity (\%)". 
A

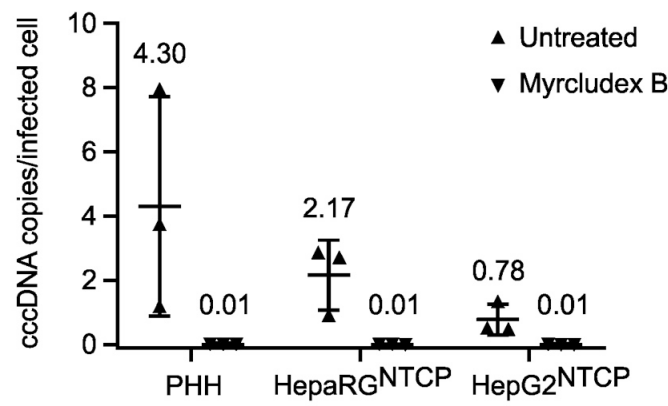

B

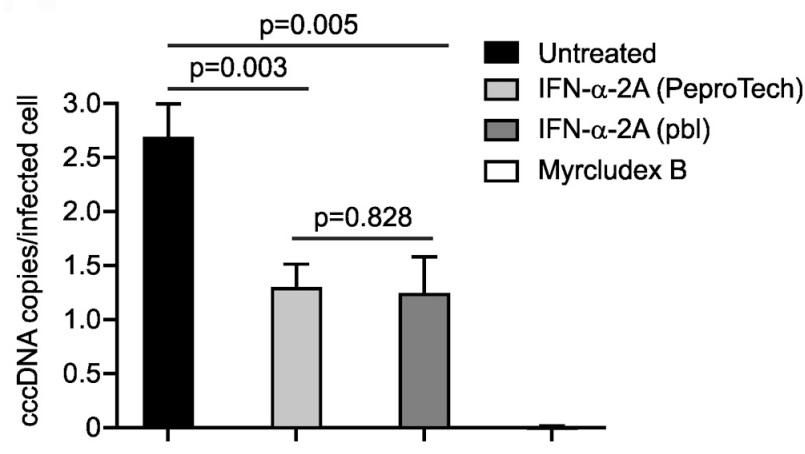

Figure 3. cccDNA levels in three in vitro models and upon IFN- $\alpha-2 a$ and Myrcludex $B$ treatment. A. PHH, differentiated HepaRG ${ }^{\text {NTCP }}$ and HepG2 ${ }^{\text {NTCP }}$ cells were infected with HBV at mges/cell of 500 . Myrcludex B $(1 \mu \mathrm{M})$, an entry inhibitor blocking cccDNA formation, was coadministered with HBV inoculum during infection. On Day 7 post infection, cccDNA copies per infected cell were determined. Data shown in triangles were collected from three independent experiments. B. HepG2 $2^{\text {NTCP }}$ cells were infected with $\mathrm{HBV}$ at mges/cell of 500 with mock treatment (untreated), co-treated with Myrcludex $\mathrm{B}(1 \mu \mathrm{M})$ during infection, or co- and posttreated with IFN- $\alpha-2 A$ at $100 \mathrm{ng} / \mathrm{ml}$ purchased from PeproTech and PBL Assay Science. On Day 7 post infection, cccDNA copies per infected cell were analyzed. Statistics: $P<0.01$ untreated versus IFN-treated; $P=0.828$ PeproTech versus PBL.

\section{$\underline{\text { Notes }}$}

The primer pair (pp1040-1996) is specific for the formed cccDNA in genotype D. Genotype D is the HBV genome in HepAD38 cell line. Users should consider this issue if they try patient-derived serum to perform in vitro infection using this protocol since HBV in patients can be any genotype and pp10401996 does not bind the formed cccDNA of other genotypes.

Genbank accession numbers of other genotypes: A(HE974370.1); B (AB540582.1); C (AB540584.1); E (HE974384.1); F (HE974369.1); G (AP007264.1); H (AB846650.1). pp1578-1867 and pp1583-2301 (Qu et al., 2018) allowing quantification of eight HBV genotypes (A-H) are suggested below. (Table 1) 
Table 1. List of primer mismatches to HBV genotypes. The numbers of base-pair mismatch of each forward and reverse primers to eight HBV genotypes are summarized below. Green squares: perfect binding; yellow squares: one base-pair mismatch still allowing template binding; red squares: not binding.

\begin{tabular}{|l|c|c|c|c|c|c|c|c|}
\hline \multirow{2}{*}{$\begin{array}{l}\text { Mismatch } \\
\text { Primer }\end{array}$} & \multicolumn{9}{|c|}{ HBV genotype } \\
\cline { 2 - 9 } p1040 (F) & A & B & C & D & E & F & G & H \\
p1996 (R)(\#) & 2 & 3 & 2 & 0 & 0 & 3 & 4 & 5 \\
\hline p972 (F) & 0 & 1 & 1 & 0 & 0 & 3 & 2 & 4 \\
p1995 (R) & 2 & 3 & 2 & 0 & 0 & 3 & 3 & 5 \\
\hline p1558 (F) & 0 & 0 & 0 & 0 & 0 & 1 & 0 & 0 \\
p1958 (R) & 0 & 1 & 1 & 0 & 0 & 2 & 2 & 1 \\
\hline p1548 (F) & 0 & 0 & 0 & 0 & 0 & 1 & 0 & 1 \\
p1886 (R) & 0 & 0 & 1 & 0 & 0 & 0 & 1 & 0 \\
\hline p1578 (F) & 0 & 0 & 0 & 0 & 0 & 0 & 0 & 0 \\
p1867 (R) & 0 & 0 & 0 & 0 & 0 & 0 & 0 & 0 \\
\hline p1583 (F) & 0 & 0 & 0 & 0 & 0 & 0 & 0 & 0 \\
p2301 (R) & 0 & 0 & 0 & 0 & 0 & 0 & 0 & 0 \\
\hline
\end{tabular}

F: forward primer; R: reverse primer. \#: The probe of this protocol is not pan-genotypic and has mismatch number as shown: $A(1), B(2), C(0), D(0), E(0), F(6), G(1), H(4)$.

\section{Recipes}

1. Culture medium

For HepG2 ${ }^{\text {NTCP }}$ cells: DMEM supplemented with $10 \%$ fetal calf serum (heat-inactivated), $100 \mathrm{U} / \mathrm{ml}$ penicillin, $100 \mathrm{\mu g} / \mathrm{ml}$ streptomycin, $2 \mathrm{mM}$ L-glutamine, 1\% MEM non-essential amino acids. For infection, add $2 \%$ dimethyl sulfoxide

For PHH and HepaRG ${ }^{\text {NTCP }}$ cells: William's medium E supplemented with $10 \%$ fetal calf serum (heat-inactivated), $100 \mathrm{U} / \mathrm{ml}$ penicillin, $100 \mu \mathrm{g} / \mathrm{ml}$ streptomycin, $2 \mathrm{mM}$ L-glutamine, 1\% MEM non-essential amino acids, $5 \mu \mathrm{g} / \mathrm{ml}$ recombinant insulin, $50 \mu \mathrm{M}$ hydrocortisone. For differentiation and infection, add $1.5 \%$ dimethyl sulfoxide

2. 10x PBS

Dissolve $80 \mathrm{~g}$ of $\mathrm{NaCl}, 2 \mathrm{~g}$ of KCl, $11.5 \mathrm{~g}$ of $\mathrm{Na}_{2} \mathrm{HPO}_{4} \cdot 2 \mathrm{H}_{2} \mathrm{O}$ and $2 \mathrm{~g}$ of $\mathrm{KH}_{2} \mathrm{PO}_{4}$ in $800 \mathrm{ml}$ of $\mathrm{H}_{2} \mathrm{O}$, adjust $\mathrm{pH}$ to 7.4 , refill $\mathrm{H}_{2} \mathrm{O}$ to $1 \mathrm{~L}$

3. Tris- $\mathrm{HCl}(1 \mathrm{M})$

Dissolve $121.14 \mathrm{~g}$ of Tris-base in $800 \mathrm{ml}$ of $\mathrm{H}_{2} \mathrm{O}$, adjust $\mathrm{pH}$ to 8.0 and refill $\mathrm{H}_{2} \mathrm{O}$ to $1 \mathrm{~L}$ 


\section{Acknowledgments}

This protocol was adapted from Qu et al., 2018. We herein acknowledge financial supports by Deutsche Forschungsgemeinschaft (DFG, German Research Foundation)-Project number 272983813-SFB/TRR179 (B.Q. and S.U.) and German Center for Infection Research (DZIF) TTU Hepatitis projects 05.704 (S.U.). We thank Pascal Mutz (DKFZ, Germany) and Florian WR Vondran (MHH, Germany) for providing PHH. We are grateful to Xue Li for critical reading of this manuscript.

\section{Competing interests}

Prof. Dr. Stephan Urban, the corresponding author, holds patents and intellectual property on Myrcludex B.

\section{Ethics}

Following written informed consent of the patients, $\mathrm{PHH}$ were isolated from liver specimens obtained after partial hepatectomy.

\section{References}

1. Bartenschlager, R. and Schaller, H. (1992). Hepadnaviral assembly is initiated by polymerase binding to the encapsidation signal in the viral RNA genome. Embo $j$ 11(9): 3413-3420.

2. Cattaneo, R., Will, H., Darai, G., Pfaff, E. and Schaller, H. (1983). Detection of an element of the SV40 late promoter in vectors used for expression studies in COS cells. Embo $j$ 2(4): 511514.

3. Guo, H., Jiang, D., Zhou, T., Cuconati, A., Block, T. M. and Guo, J. T. (2007). Characterization of the intracellular deproteinized relaxed circular DNA of hepatitis B virus: an intermediate of covalently closed circular DNA formation. J Virol 81(22): 12472-12484.

4. Lempp, F. A., Qu, B., Wang, Y. X. and Urban, S. (2016). Hepatitis B virus infection of a mouse hepatic cell line reconstituted with human sodium taurocholate cotransporting polypeptide. $J$ Virol 90(9): 4827-4831.

5. Lempp, F. A., Wiedtke, E., Qu, B., Roques, P., Chemin, I., Vondran, F. W. R., Le Grand, R., Grimm, D. and Urban, S. (2017). Sodium taurocholate cotransporting polypeptide is the limiting host factor of hepatitis B virus infection in macaque and pig hepatocytes. Hepatology 66(3): 703-716.

6. Levrero, M., Testoni, B. and Zoulim, F. (2016). HBV cure: why, how, when? Curr Opin Virol 18: 135-143.

7. Li, X., Zhao, J., Yuan, Q. and Xia, N. (2017). Detection of HBV Covalently Closed Circular DNA. Viruses 9(6): E139. 
8. Liang, T. J., Block, T. M., McMahon, B. J., Ghany, M. G., Urban, S., Guo, J. T., Locarnini, S., Zoulim, F., Chang, K. M. and Lok, A. S. (2015). Present and future therapies of hepatitis B: From discovery to cure. Hepatology 62(6): 1893-1908.

9. Long, Q., Yan, R., Hu, J., Cai, D., Mitra, B., Kim, E. S., Marchetti, A., Zhang, H., Wang, S., Liu, Y., Huang, A. and Guo, H. (2017). The role of host DNA ligases in hepadnavirus covalently closed circular DNA formation. PLoS Pathog 13(12): e1006784.

10. Margeridon, S., Carrouee-Durantel, S., Chemin, I., Barraud, L., Zoulim, F., Trepo, C. and Kay, A. (2008). Rolling circle amplification, a powerful tool for genetic and functional studies of complete hepatitis B virus genomes from low-level infections and for directly probing covalently closed circular DNA. Antimicrob Agents Chemother 52(9): 3068-3073.

11. Mu, D., Yan, L., Tang, H. and Liao, Y. (2015). A sensitive and accurate quantification method for the detection of hepatitis B virus covalently closed circular DNA by the application of a droplet digital polymerase chain reaction amplification system. Biotechnol Lett 37(10): 2063-2073.

12. Nassal, M. (2015). HBV cccDNA: viral persistence reservoir and key obstacle for a cure of chronic hepatitis B. Gut 64(12): 1972-1984.

13. Ni, Y. and Urban, S. (2017). Hepatitis B Virus infection of HepaRG cells, HepaRG-hNTCP cells, and Primary Human Hepatocytes. Methods Mol Biol 1540:15-25.

14. Qu, B., Ni, Y., Lempp, F. A., Vondran, F. W. R. and Urban, S. (2018). T5 exonuclease hydrolysis of hepatitis $B$ virus replicative intermediates allows reliable quantification and fast drug efficacy testing of covalently closed circular DNA by PCR. J Virol 92(23).

15. Schreiner, S. and Nassal, M. (2017). A Role for the Host DNA Damage Response in Hepatitis B Virus cccDNA Formation-and Beyond? Viruses 9(5): E125.

16. Tu, T., Budzinska, M. A., Shackel, N. A. and Urban, S. (2017). HBV DNA Integration: Molecular mechanisms and clinical implications. Viruses 9(4): E75.

17. Xu, C. H., Li, Z. S., Dai, J. Y., Zhu, H. Y., Yu, J. W. and Lu, S. L. (2011). Nested real-time quantitative polymerase chain reaction assay for detection of hepatitis $B$ virus covalently closed circular DNA. Chin Med J (Engl) 124(10): 1513-1516.

18. Yu, M., Yang, H., Xie, X., Barauskas, O., Feng, J., Gamelin, L., Xu, S., Delaney, W. and Cheng, G. (2015). 2015 International HBV Meeting. Poster number 43. October 4, 2015-October 8 , 2015, Bad Nauheim, Germany. 